\title{
QUEEN'S
QNEIVERSITY
BELFAST
}

\section{Conversion of haloform to carbonate by iridium N-heterocyclic carbene complexes and silver(I) oxide}

Marr, A. C., Morgan, P. J., Saunders, G. C., \& Thomas, H. P. (2019). Conversion of haloform to carbonate by iridium N-heterocyclic carbene complexes and silver(I) oxide. Dalton Transactions.

https://doi.org/10.1039/C8DT04456B

\section{Published in:}

Dalton Transactions

\section{Document Version:}

Peer reviewed version

Queen's University Belfast - Research Portal:

Link to publication record in Queen's University Belfast Research Portal

\section{Publisher rights}

(c) The Royal Society of Chemistry 2019. This work is made available online in accordance with the publisher's policies. Please refer to any applicable terms of use of the publisher.

\section{General rights}

Copyright for the publications made accessible via the Queen's University Belfast Research Portal is retained by the author(s) and / or other copyright owners and it is a condition of accessing these publications that users recognise and abide by the legal requirements associated with these rights.

Take down policy

The Research Portal is Queen's institutional repository that provides access to Queen's research output. Every effort has been made to ensure that content in the Research Portal does not infringe any person's rights, or applicable UK laws. If you discover content in the Research Portal that you believe breaches copyright or violates any law, please contact openaccess@qub.ac.uk. 


\title{
Conversion of haloform to carbonate by iridium $\mathrm{N}$-heterocyclic carbene complexes and silver(I) oxide
}

\author{
Andrew C. Marr, ${ }^{a}$ Patrick J. Morgan, ${ }^{a}$ Graham C. Saunders ${ }^{* b}$ and Hayden P. Thomas ${ }^{b}$
}

The reaction between haloform, the complexes $\left[\mathrm{Cp}^{*} \operatorname{IrCl}_{2}(\kappa \mathrm{C}\right.$ $\left.\left.\mathrm{MeNC}_{3} \mathrm{H}_{2} \mathrm{NCH}_{2} \mathrm{Ar}\right)\right]\left(\mathrm{Ar}=\mathrm{C}_{6} \mathrm{H}_{3} \mathrm{~F}_{2}-2,6, \mathrm{C}_{6} \mathrm{H}_{3} \mathrm{~F}-2-\mathrm{Cl}-6, \mathrm{C}_{6} \mathrm{H}_{3} \mathrm{Me}_{2}-2,6\right)$ and silver(I) oxide proceeded by carbon-halogen bond fission to yield the carbonate complexes $\left[\mathrm{Cp} * \operatorname{Ir}\left(\kappa^{2} \mathrm{O}-\mathrm{CO}_{3}\right)\left(\kappa \mathrm{C}-\mathrm{MeNC}_{3} \mathrm{H}_{2} \mathrm{NCH}_{2} \mathrm{Ar}\right)\right]$.

Pentamethylcyclopentadienyl imidazol-2-ylidene iridium complexes, $\mathrm{Cp} * \operatorname{Ir}(\mathrm{NHC})$, display interesting reactivity, such as activation of alkyl carbon-hydrogen bonds ${ }^{1,2}$ and carbonfluorine bonds, ${ }^{3}$ and catalytic activity, including water oxidation, ${ }^{4,5}$ transfer hydrogenation, ${ }^{6,7}$ dynamic kinetic resolution, ${ }^{8}$ hydrogen transfer initiated dehydration, ${ }^{9}$ the alkylation of amines, ${ }^{10}$ and dehydrogenative oxidation of alcohols. ${ }^{11}$ Cyclometallation involving carbon-hydrogen bond activation induced by base has been reported for NHC ligands bearing aryl, benzyl and alkyl substituents. ${ }^{2,4,11,12}$ Recently we reported cyclometallation by carbon-halogen bond activation induced by silver particles for complexes with halogen atoms at both ortho positions of a benzyl substituent. ${ }^{3,13}$

In a number of in situ NMR studies of carbon-halogen bond activation other minor products were formed when the silver particles were generated mechanically from silver(I) oxide. ${ }^{3}$ It was considered possible that these were formed by a reaction between the iridium complex and residual silver(I) oxide. In situ NMR experiments, conducted without excluding air and moisture, confirmed that, on treatment with silver(I) oxide, the complex [Cp* $\left.\operatorname{IrCl}_{2}\left(\kappa \mathrm{C}-\mathrm{MeNC}_{3} \mathrm{H}_{2} \mathrm{NCH}_{2} \mathrm{C}_{6} \mathrm{H}_{3} \mathrm{~F}-2-\mathrm{Cl}-6\right)\right]$ (1a) ${ }^{13}$ in deutero-chloroform underwent a reaction over several hours to afford the carbonate complex $\left[\mathrm{Cp} * \operatorname{Ir}\left(\kappa^{2} \mathrm{O}-\mathrm{CO}_{3}\right)(\kappa \mathrm{C}-\right.$ $\mathrm{MeNC}_{3} \mathrm{H}_{2} \mathrm{NCH}_{2} \mathrm{C}_{6} \mathrm{H}_{3} \mathrm{~F}-2-\mathrm{Cl}-6$ )] (2a) cleanly in high yield. The identity of $\mathbf{2 a}$ was confirmed by a single crystal X-ray diffraction study of the dihydrate, and by comparison of its NMR spectral data with an authentic sample prepared by treatment of 1a with silver carbonate, in particular the resonance at $\delta_{c}$ 168.1, which is consistent with $\kappa^{2} \mathrm{O}$-bound carbonate of iridium NHC complexes. ${ }^{14}$

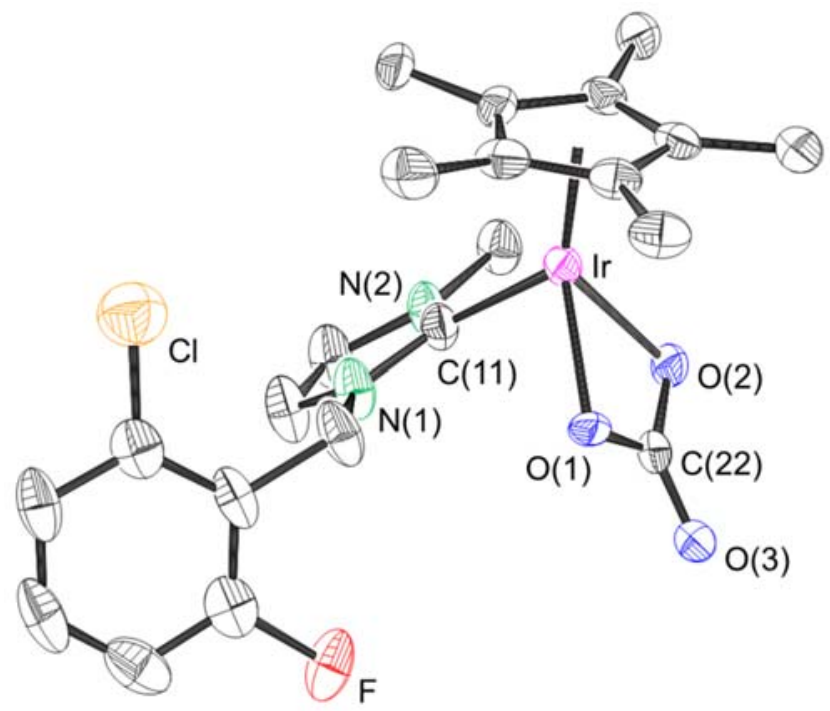

Fig. 1 Molecular structure of $\mathbf{2 a}$. Thermal ellipsoids represent $50 \%$ probability. Hydrogen atoms have been omitted for clarity. Selected bond distances $(\AA)$ and angles $\left({ }^{\circ}\right)$ : Cp*-Ir 1.796(7), Ir-C(11) 2.049(6), Ir-O(1) 2.131(4), Ir-O(2) 2.133(4), $C p^{*}-\mathrm{Ir}-\mathrm{C}(11) \quad 131.4(3), \quad C p^{*}-\mathrm{Ir}-\mathrm{O}(1) \quad 132.8(2), \quad C p^{*}-\mathrm{Ir}-\mathrm{O}(2)$ 133.0(2), $\quad C(11)-1 r-O(1) \quad 86.8(2), \quad C(11)-1 r-O(2) \quad 86.3(2)$, $\mathrm{O}(1)-\mathrm{Ir}-\mathrm{O}(2)$ 62.23(15).

Both metal reagents are necessary for the reaction: no reaction was observed between chloroform and silver(I) oxide, nor between chloroform and $\mathbf{1 a}$. The combination of $\mathbf{1 a}$ and silver(I) oxide was also observed to react with dichloromethane to form $\mathbf{2 a}$, although more slowly than with chloroform, and with tetrahydrofuran, albeit much less cleanly. A reaction was observed with dimethylsulphoxide, but this occurred sufficiently slowly to allow an in situ NMR study of the reaction with chloroform to be conducted: adding a drop of chloroform to a deutero-dimethylsulphoxide solution of $\mathbf{1} \mathbf{a}$ with silver(I) oxide produced $\mathbf{2 a}$ more rapidly and cleanly than reaction with dimethylsulphoxide alone. Complex $2 \mathrm{a}$ was also produced when chloroform was replaced by bromoform or iodoform. Formation of dihalomethane was also evident with these two haloforms. In situ NMR experiments revealed that haloform was consumed as 2 a was formed (Fig. 2). 


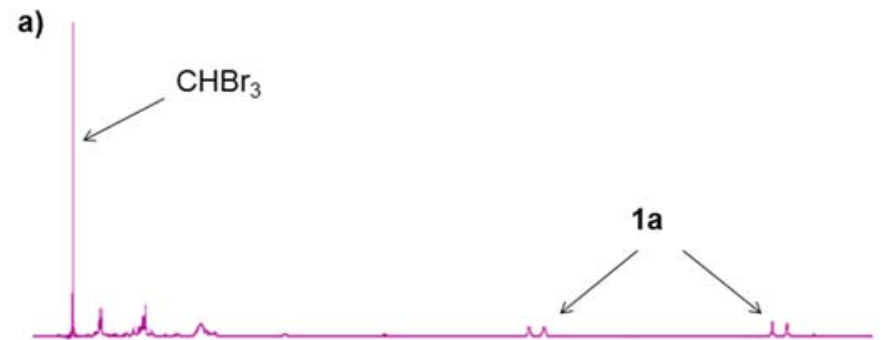

b)

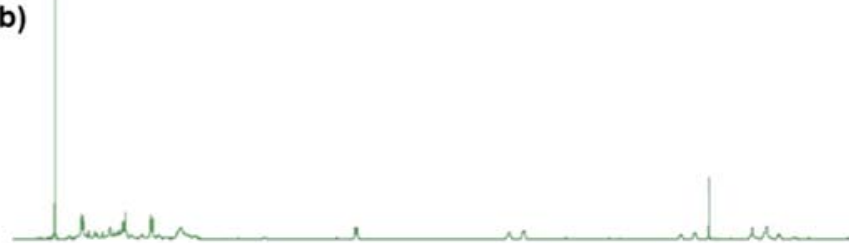

c)

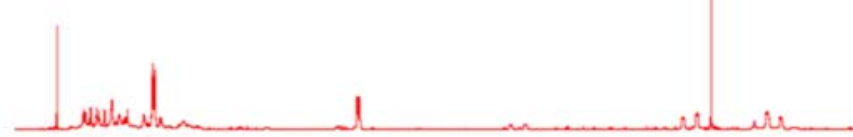

d)

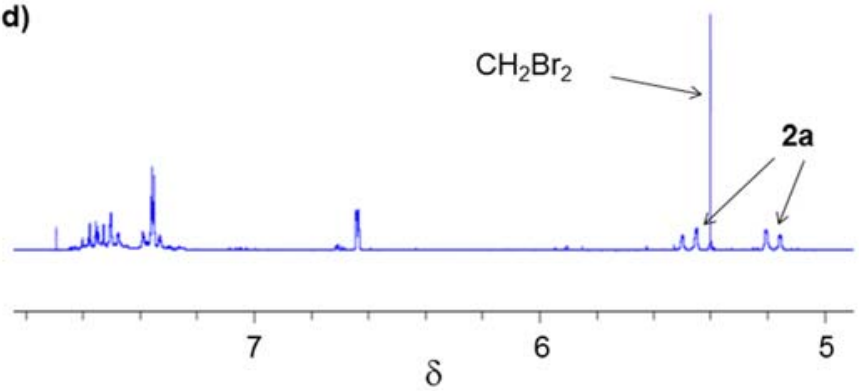

Fig. 2 Portions of ${ }^{1} \mathrm{H}$ NMR spectra of the reaction between 1a, silver(I) oxide and bromoform in deutero-dimethylsulphoxide, with the methylene hydrogen atoms of $1 \mathbf{a}$ and $\mathbf{2 a}$ indicated. a) On addition of silver oxide, and after b) after 7 days, c) 20 days and d) 30 days.

The results strongly suggest that the reaction involves the transformation of haloform to carbonate. This is supported by the observation that the reaction also occurred under anaerobic conditions, thus precluding atmospheric carbon dioxide as the source of carbonate. Further, no reaction was observed between the rhodium analogue of 1 a and silver(I) oxide from the same batch, but formation of $\left[\mathrm{Cp} * \mathrm{Rh}\left(\kappa^{2} \mathrm{O}\right.\right.$ $\left.\left.\mathrm{CO}_{3}\right)\left(\kappa \mathrm{C}-\mathrm{MeNC}_{3} \mathrm{H}_{2} \mathrm{NCH}_{2} \mathrm{C}_{6} \mathrm{H}_{3} \mathrm{~F}-2-\mathrm{Cl}-6\right)\right]$ occurred on treatment with silver carbonate. Therefore, contamination of the silver(I) oxide was not the reason for formation of carbonate.

It is proposed that the oxygen atoms of the carbonate are derived from the silver(I) oxide, and the chloride ligands of the iridium complexes dissociate, or are abstracted, and form silver chloride. The halogen atoms of the haloform form silver halide and the haloform carbon atom undergoes a formal oxidation from +II to +IV on formation of carbonate, and so a reduction of two equivalents of silver from +1 to 0 is expected (Scheme 1). Consistent with the proposed scheme, analysis of the residue of the reaction involving chloroform was consistent with silver chloride and elemental silver.
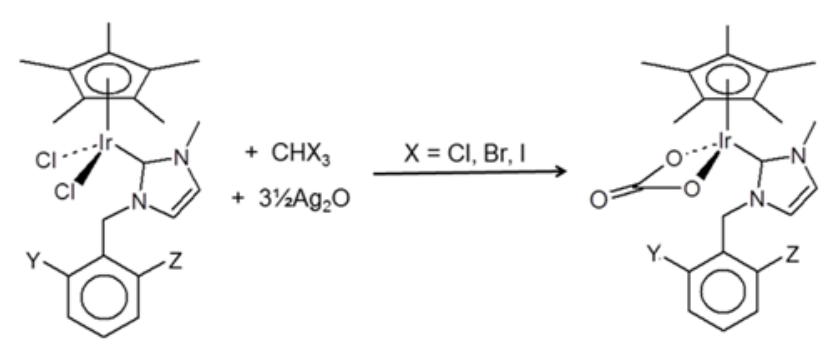

1a $Y=F, Z=C l$

1b $Y=Z=F$

1c $Y=Z=M e$

$+2 \mathrm{AgCl}+3 \mathrm{AgX}+2 \mathrm{Ag}$

$+1 / 2 \mathrm{H}_{2} \mathrm{O}$

2a $Y=F, Z=C l$

2b $Y=Z=F$

2c $Y=Z=M e$

Scheme 1 Reaction of haloform with complexes $1 \mathbf{a}-\mathbf{c}$ and silver(I) oxide.

The reaction mechanism is unknown, but, based on a lack of reaction between chloroform and the individual metal reagents, it is likely that the first step involves a reaction between 1a and silver(I) oxide. Since no obvious intermediate is apparent in the NMR spectra, this would be the rate determining step. It also suggests that the subsequent reaction is rapid. Further studies revealed that the reaction is not restricted to $1 \mathrm{a}$, but occurs for the analogous complexes with fluorine atoms $(\mathbf{1} \mathbf{b})^{13}$ or methyl groups $(\mathbf{1} \mathbf{c})^{7}$ at both ortho sites. The requirement for the reaction appears to be the absence of ortho substituents that can undergo base-induced bond activation to give a cyclometallated product. ${ }^{12,13}$

In summary we have demonstrated that the complex [Cp* $\left.\mathrm{IrCl}_{2}\left(\kappa \mathrm{C}-\mathrm{MeNC}_{3} \mathrm{H}_{2} \mathrm{NCH}_{2} \mathrm{C}_{6} \mathrm{H}_{3} \mathrm{~F}-2-\mathrm{Cl}-6\right)\right]$, and two analogues, convert haloform to carbonate on treatment with silver(I) oxide. The rhodium analogue does not show similar reactivity.

\section{Conflicts of interest}

There are no conflicts to declare.

\section{Notes and references}

1 M. Prinz, M. Grosche, E. Herdtweck and W. A. Herrmann, Organometallics, 2000, 19, 1692.

2 R. Corberán, M. Sanaú and E. Peris, Organometallics, 2006, 25, 4002 .

3 H. P. Thomas, Y.-M. Wang, F. Lorenzini, S. J. Coles, P. N. Horton, A. C. Marr and G. C. Saunders, Organometallics, 2017, 36, 960.

4 T. P. Brewster, J. D. Blakemore, N. D. Schley, C. D. Incarvito, N. Hazari, G. W. Brudvig and R. H. Crabtree, Organometallics, 2011, 30, 965.

5 Z. Codolà, J. M. S. Cardoso, B. Royo, M. Costas and J. LloretFillol, Chem. Eur. J., 2013, 19, 7203.

6 R. Corberán, M. Sanaú and E. Peris, Organometallics, 2007, 26, 3492.

7 Y. Ma, Y. Wang, P. J. Morgan, R. E. Jackson, X. Liu, G. C. Saunders, F. Lorenzini and A. C. Marr, Catalysis Today, 2018, 307, 248.

8 A. C. Marr, C. L. Pollock and G. C. Saunders, Organometallics, 2007, 26, 3283.

9 A. C. Marr, F. Lorenzini, Y. Wang, M. Rebros and G. C. Saunders, Green Chemistry, 2016, 18, 1751.

10 A. Fernandes and B. Royo, Chem CatChem, 2017, 9, 3912. 
11 S. Gülcemal, D. Gülcemal, G. F. Whitehead and J. Xiao, Chem. Eur. J., 2016, 22, 10513.

12 R. Corberán, M. Sanaú and E. Peris, J. Am. Chem. Soc., 2006, 128, 3974.

13 A. C. Marr, G. C. Saunders, H. P. Thomas and Y.-M. Wang, Inorg. Chim. Acta, 2019, 486, 1.

14 (a) C. S. to Brinke and F. E. Hahn, Eur. J. Inorg. Chem., 2015, 3227; (b) S. Ibañez, M. Poyatas and E. Peris, Dalton Trans., 2016, 45, 14154 